\title{
The Formation of a Small Polity
}

More than two decades ago Barrington Moore, in his Social Origins of Dictatorship and Democracy, examined the paths different states have followed when moving into the modern age and assessed the ensuing variation in political systems. Concentrating on a few big countries where a certain social process had 'worked itself out,' ${ }^{1}$ he deliberately neglected the small countries:

The fact that the smaller countries depend economically and politically on big and powerful ones means that the decisive causes of their politics lie outside their own boundaries. It also means that their political problems are not really comparable to those of larger countries. Therefore a general statement about the historical preconditions of democracy or authoritarianism covering small countries as well as large would very likely be so broad as to be abstractly platitudinous. ${ }^{2}$

When inverted, Moore's observation encapsulates the basic problem examined in this book. What are the decisive factors conditioning twentieth-century politics in smaller countries that are economically and politically dependent on big ones? Even though the question was dismissed by Moore, it is worth asking simply because most countries are small, and most people live in polities that are dependent on distant centres of power. In what ways, then, has dependence on powerful states influenced preconditions, forms, and outcomes of collective action in small polities? How has it affected the occurrence of revolutions, other large-scale conflicts, and the institutionalisation of political systems when these polities enter into an era of mass politics?

In this study answers to these questions will be sought based on the experience of Finland, one of the smaller European polities economically and politically dependent on big centres. It is also one of the countries called 'successor states' between the world wars. The state structures and internal conflicts of these polities, which formed a geographically connected area between Russia

1 Moore 1966, p. xii.

2 Moore 1966, p. xiii.

(C) KONINKLIJKE BRILL NV, LEIDEN, 2019 | DOI:10.1163/9789004386174_002

This is an open access chapter distributed under the terms of the CC BY-NC-ND $4_{R} 0$ license lapuro $_{\text {- }} 9789004386174$ 
and other major European powers, were dramatically affected by World War I, and the countries reached a critical point in their political development at one and the same moment.

These characteristics set this group of polities apart from other small countries for which this perspective is also relevant, namely the Third World countries that have won independence from colonial rule in the twentieth century. Although it is true that dependence through capitalist commercialisation and interstate competition has powerfully shaped state-making and political conflicts in both classes of polities, only the European cases were dependent on backward empires, only they were geographically contiguous with the metropoles themselves, and only they experienced a simultaneous, sudden, and complete collapse of the metropolitan country. John Dunn's distinction between world war and decolonisation as the two major nondomestic processes related to the important revolutionary challenges in the twentieth century captures the main difference between the European and the other cases. ${ }^{3}$

The focus here is on Finland, which means that the problems will be dealt with in the context of a single country. The main thrust of the book will concern the nature of political and economic dependence and the particular political consequences it had in the Finnish case. At the end of the book a few comparisons with other Eastern European polities will be made to show the distinctiveness of certain Finnish features. Because Finland is an example of a whole class of countries, analysis of the Finnish experience, together with the comparisons with other countries, should help to put political development in this class of countries into perspective. The analysis may throw some light more generally on the development of politics in the dependent Eastern European countries and, ultimately, on how the political and economic impact of the big powers is reflected in the internal processes of the smaller countries.

\section{A Comparative Perspective}

From what perspective should early twentieth-century politics in Finland and other small Eastern European polities be viewed? If the small countries really are a case apart, various well-known models of political development cannot be used, because they are based, explicitly or implicitly, on the experience of

3 Dunn 1977, p. 98. Actually, Dunn speaks of revolutionary success and of big and small countries alike. The outcome in the small polities was presumably much more dependent on outside forces than in the large ones. 
the large European national states. ${ }^{4}$ Moreover, it is by no means obvious that even the forms of collective action found in small countries are the same as those in big, established European states. Thus, if the causes of political transformation in the small European states are substantially different from those in the larger ones, then both the 'phases' or 'sequences' of political development and the nature of collective action in the two cases may likewise differ markedly.

During the years since Moore's work appeared, the problem of comparability has been approached in at least two new systematic ways. First, it has been pointed out that even in large states political transformation is dependent on the capitalist world-economy and on processes involving other states or the international state system. In this view Moore's distinction is not as unambiguous as he assumed it to be. The analysis of the relationship between states and the international system should not be confined to small polities but should be extended to large ones - as Theda Skocpol has forcefully maintained in her comparison of the French, Russian, and Chinese revolutions. ${ }^{5}$ Immanuel Wallerstein's and Perry Anderson's delineations of the rise of the European world-economy and the European state system can also be seen in this light. ${ }^{6}$ In both these analyses the emergence of the various individual states depends on their relations to the entire emerging structure: the trajectories of particular states are conditioned by their different relations to the system as a whole.

This perspective obviously suggests one way in which Finland can be compared with other states, even large ones. For example, it would appear useful to view the Finnish revolution of $1917-18$ as the outcome of the interplay of domestic and international processes and in this sense similar to the 'great' revolutions examined in Skocpol's study. This approach, unlike theories of political development, does not imply that similarities between large and small countries must be found. Rather, it facilitates comparisons that should enable us to determine what was specific to the Finnish experience itself. For Finland, the significance of the international context is obvious; therefore, looking at other European states and their emergence in an international perspective may help to identify the key features of Finland's development. This does not necessarily mean that 'general statements' will be applicable to Finland, but it may help us see how the internal and external factors important throughout Europe were linked together in this particular case.

4 See Tilly $1975 \mathrm{c}$.

5 Skocpol 1979. Also Skocpol 1982, pp. 367-73; Østerud 1978b, pp. 176-8.

6 Wallerstein 1974-80; P. Anderson 1974. 
This approach alone, however, is not sufficient. It hardly suggests more than a general course for considering a northeastern latecomer state such as Finland. In order to determine what was specifically Finnish as opposed to what was common with other countries, notably the other small Eastern European polities, the emergence of Finland should be viewed more concretely and in a large perspective.

Perhaps the most ambitious effort in this, second, direction is Stein Rokkan's 'conceptual map of Europe.7 In commenting on Barrington Moore's decision to concentrate on leading countries, Rokkan argued that the analysis should not be restricted to large and powerful leading polities when examining specific regions such as Europe. 'On the contrary, the purpose is to account for variations among all the distinctive polities in the region, and this requires direct attention to the possible consequences of such factors as size, economic resource potential and location in the international power system' ${ }^{8}$ Thus Rokkan developed schemes that account for variations in the Western European party systems and in the scope for state-making in Europe.

In his conceptual map of Europe, state-making patterns vary along two major axes of development. On the West-East axis indicating the economic resource bases of the state-making centres, Finland is a region where surplus was extracted from agricultural labour and not, as in the West, from a highly monetised economy. Together with the Baltic territories, Bohemia, Poland, and Hungary, Finland was a 'landward buffer' in which both territorial centres and city networks were weakly developed. On the North-South axis measuring conditions for rapid cultural integration - that is, nation-building - Finland falls in the same class as Sweden, Denmark, Norway, and Iceland. In these northern countries, national Protestant churches marked off religious and linguistic areas into which cultural penetration could occur fairly easily. In the South, in contrast, religious 'supraterritoriality' created obstacles for cultural integration. ${ }^{9}$ It is in this perspective - of an alliance between statemakers and landowners for extracting food and manpower and of separate cultural identities developing into political entities - that the major characteristics of Finnish state formation should be viewed.

Clearly, this model relates Finland to other political entities in Europe and provides a starting point for comparing state-making in Finland with statemaking elsewhere in Europe. It helps us to see that the Finnish state-making

7 Allardt 1981b, p. 264.

8 Rokkan 1969, p. 6 o.

9 Rokkan 1973, pp. 80-4; Rokkan 198o, pp. 178-183; Tilly 1981, pp. 10-13. 
experience resembles that not only in the fringe between Russia and the other major European powers but also in Scandinavia. Nonetheless, this approach has a major problem: by placing Finland or any other polity in a European context, it fails to take into account the way the entities interact. The international system is seen as the sum total of its component parts rather than as an environment affecting, perhaps in contradictory ways, the destinies of single entities. The model is essentially taxonomic; it does not really address Moore's problem, that is, the special features of internal developments in small polities that result from their dependence on big ones. Basically, as Charles Tilly puts it, it treats national experiences as 'cases' that result from different combinations of certain central variables. ${ }^{10}$

Sweden, to take an obvious instance, is not simply a 'case' located somewhere in the northern reaches of a giant cross-tabulation. The Sweden which appears on Rokkan's conceptual map is a shrunken remainder of the expansive power which at one time or another dominated Norway, Finland, Estonia, Livonia, and other important parts of the North. Can we reconstruct the political development of Sweden - or, for that matter, of Norway, Finland, Estonia and Livonia - without taking that interaction directly into account? ${ }^{11}$

Tilly himself has explicitly suggested that small polities should be viewed as dependent on big ones. He also proposes a dichotomy exemplified by the above distinction between Sweden, on the one hand, and Norway, Finland, Estonia (Estland), and Livonia (Livland), on the other. The distinction represents the first two steps in the general movement toward a worldwide state system that originated in Europe.

The first phase was the formation of the first great national states. This involved commercial and military competition followed by economic penetration into the remainder of Europe and parts of the world outside Europe. The expansive processes were facilitated by the absence of important concentrations of power immediately outside the areas in which the substantial states were forming, as well as by the availability of new territories for expansion, conquest, and extraction of resources. What took place in this period, from approximately 1500 to 1700 , was the consolidation of a system of states acknowledging, and to some extent guaranteeing, one another's existence. The Treaty

10 Tilly 1981, 16. Also Allardt 1981b, pp. 269-70.

11 Tilly $1981,16$. 
of Westphalia (1648) played an important part in laying the foundation for the European state system. ${ }^{12}$ By the end of the period, the substantial powers in Europe included such national states as England, France, Brandenburg-Prussia, and Sweden, as well as three empires: the Russian, the Austro-Hungarian, and the Ottoman.

Whereas the first phase in the development toward a worldwide state system involved the formation of a few early national states and empires with ethnically distinct centres, the second phase consisted of the division of most of Europe into distinct national states through wars, alliances, and a great variety of other manoeuvres. The earlier phase in state-making seriously constrained the second. New states increasingly came into being as a result of wars between established members of the state system. The Treaty of Westphalia, the Congress of Vienna (1815), and the Treaty of Versailles (1919) constitute dramatic demonstrations of this point. ${ }^{13}$ And Finland is a good example of such a new state: the two major landmarks in its movement toward statehood were the Napoleonic Wars and World War I.

This pattern of the emergence of a system of a few early states followed by the regrouping of the remainder of Europe into a system of states subject to the constraints of the initial system (which by no means remained immutable) helps to place the Finnish and other Eastern European experience in perspective. It is the final phase of the process that concerns us here, however. In this phase, it is most important that the three great multinational empires, Russia, Austria-Hungary, and the Ottoman Empire, were dismembered. Each of them created somewhat different preconditions for the consolidation of national minorities. ${ }^{14}$ The so-called successor states of the empires in the late 1800 and early 19oos include Finland, Estonia, Latvia, Lithuania, Poland, Czechoslovakia, Hungary, Romania, Bulgaria, Yugoslavia, and Albania. Many of these countries were 'unhistoric nations', in the sense that they were not linked to existing or even historically remembered polities. This was the last wave of creation of distinct national states in Europe, and it came about as a consequence of international crisis and/or conflict between the established members.

The distinction implies that state-making processes in the latecomer states were different from those in the early substantive states. In the early cases, the only political units that could survive were ones privileged with a relatively protected position in time and space, the availability of extractable resources, a

\footnotetext{
12 Tilly 1975b, pp. 30, 44-5; Tilly 1975c, pp. 636-7. See also Kiernan 1965, pp. 32-6.

13 Tilly 1975 b, pp. 46, 74-5; Tilly 1975c, pp. 636-7.

14 The Poles, of course, were divided among various empires, as were the Romanians to a certain extent.
} 
continuous supply of political entrepreneurs, success in war, homogeneity (initial or created) of the subject population, and strong coalitions between the central power and major segments of the landed elite..$^{15}$ The transformation of these states was largely a by-product of attempts by the central power to consolidate its position and to respond to challenges both external and internal. The state-making process, then, was intimately bound up with the conduct of war, the building of armies, the levying and regularisation of taxes, and the growth of the administrative apparatus. Tilly conceives of early state-making as a process in which the state-makers who were trying to survive and expand were forced to create standing armies for use against rivals elsewhere as well as rebels at home: 'States have grown up as warmaking organizations.'16 The maintenance of armies made it necessary to squeeze more revenue from the populace, and the very existence of the army in turn facilitated this process, thereby contributing to the consolidation of central power. At the same time, various coalitions were formed between the central power and the major dominant classes.

In short, the main processes that brought the national state to a dominant position were not only coercive and extractive; they were also internal. It is true that the creation of standing armies resulted from struggles between states, and therefore external threats ultimately played an important role. But the relation of the rulers to the ruled within the state was decisive. Territorial consolidation, centralisation, differentiation of the instruments of government, and monopolisation of the means of coercion (that is, the fundamental state-making processes) were all imposed on the subject population by the emerging central power and its main allies. ${ }^{17}$ This view is in line with other conceptions of European state formation. It is congruent with Max Weber's formulations on big (European) states. He views them in terms of his conception of the state as an apparatus of domination, which provides a model for analysing, above all, the internal processes of a political unit. ${ }^{18}$ According to Perry Anderson, to take another example, the absolutist states in the West emerged in response to the internal decomposition of feudalism. As a new apparatus of feudal domination against the peasant masses, absolutism succeeded in obtaining the widespread commutation of dues. The same priority of the intra-state power relations was true in the East, despite the fact that there absolutism was largely a result of external pressures. The more advanced societies of the West were able to

\footnotetext{
15 Tilly 1975 b, p. 40.

16 Tilly, Tilly and Tilly 1975, pp. 259-63 (quotation from p. 259).

17 Tilly 1975 b, pp. 42, 71; Tilly 1975c, pp. 632-3.

18 Weber 1948, pp. 77-8, 82-3; Collins 1968, p. 48.
} 
plunder the more retarded areas of Eastern Europe. To protect themselves, the countries of the East had to raise armies, and strong armies required strong states. ${ }^{19}$

This centuries-long process did not repeat itself in the second phase of statemaking. The later the state-making process, the less adequate the above processes are for explaining the formation, survival, or growth of the state. New states were more or less created by existing ones, ${ }^{20}$ as a result of crises and rivalries in the international state system, which led to wars and the break-up of empires subject to protracted pressures.

This difference meant that relations between the major local classes and the central power evolved differently. In other words, the connection between (1) state structures and (2) class relations was not the same as in the early substantive states. In the small dependent polities, class relations were not as institutionalised in political structures, which were in any case recent or otherwise weak. This difference then shaped the nature of local political organisation and collective action, which were reflected both in (3) national integration - that is, cultural homogenisation and nation-building - and in (4) class integration that is, class-based collective action.

First, the position of the state apparatus vis-à-vis the subject population was dissimilar in the established states as contrasted with the latecomers. In the former the state apparatus had been consolidated over the course of centuries and had come to correspond to class relations in the core areas. In the latter this apparatus was often of recent origin or had been imposed by the metropolitan country. Prior to independence, the position of the dominant groups was usually guaranteed by the metropolitan power, and inherited administrative institutions and state structures did not necessarily correspond to purely local power relations. The post-World War I Baltic countries constitute an excellent example of this situation. The relationship between the dominant groups and the subject population was much less institutionalised, and the state less autonomous, than in the early national states.

It is in this context of political structures that the second factor, class relations, should be viewed. In the last century the expansion of the Western capitalist market dissolved feudal ties and reshaped agrarian class structures in Eastern Europe. Large numbers of emancipated peasants were allotted minuscule holdings or no land at all, except in the Balkans, where backward small farming became predominant. The consolidation of large capitalist estates was

19 P. Anderson 1974, pp. 18, 196-202; Gourevitch 1978, pp. 427-8.

$20 \quad$ Tilly 1975 c, p. 636. 
not immediately accompanied by the growth of an industrial proletariat in the cities. It was common to see class boundaries imposed along ethnic lines: in a number of minority areas, local peasantries were confronted with non-native landlords. The level of literacy was much lower than in the West and Scandinavia, and popular organisation was weak. ${ }^{21}$ All in all, large strata of the peasantry in minority regions were hurt by economic dependence on the developed West. Examples of the effect of this class structure on collective action are the extensive peasant unrest in the Baltic Provinces of Russia in 1905 and the great Romanian peasant revolt in 1907.

Third, ethnic considerations played a much more prominent role in the later cases. The formation of the state was given momentum by the aspirations of ethnically distinct groups, or, more precisely, by the actions of their elites. In the earlier phase of state-making, national consciousness, participation, and commitment generally developed only after strong states had been formed, as a consequence of deliberate actions on the part of the central power. ${ }^{22}$ In the Eastern European latecomer states, the process was reversed: ethnic similarities led to the emergence of a national consciousness before the formation of the state. ${ }^{23}$ This difference should be borne in mind when assessing the role of nationalism in the two cases.

Fourth, in the nineteenth century and the beginning of the twentieth, classbased collective action took place in different conditions in the two classes of countries. During this period there were increasing demands for the extension of political rights in Europe, the working-class movement being the main challenger in the old and new states alike. If, following Charles Tilly, ${ }^{24}$ collective action is conceived of as resulting from changing combinations of interests, organisation, mobilisation, and opportunity, it is particularly the opportunity that distinguishes the latecomer states from the earlier (Western) European national states. The difference merits attention because the bulk of the relevant literature has, more or less implicitly, taken the experience of the early Western European states as their starting point.

The Western experience suggests that collective action was the result of a gradual but painful process running from common interests through organisation and mobilisation to collective action. This conception pervades the writings of several analysts of political transformations and revolutions: it is

\footnotetext{
21 Berend and Ránki 1974, pp. 25-58; Orridge and Williams 1982, pp. 24, 29, 32.

22 Tilly 1975 b, p. 70.

23 Chlebowczyk 1980, pp. 21-2, 214; Eley 1981, pp. 96-105; Orridge 1982, pp. 44-5.

24 Tilly 1978 , pp. $7-8$.
} 
present in Barrington Moore's great book; it figures in the Tilly's analysis of the rebellious century extending from 1830 to 1930 in France, Italy, and Germany; and it is a central theme in E.P. Thompson's book on the making of the English working class. ${ }^{25}$ Political rights were gradually won through hard and often protracted struggles in which the workers slowly learned to organise, mobilise, and act collectively against state machineries, first in strikes and then, after gaining some rights, in elections fought with their own parties. ${ }^{26}$ Each step of the expansion of rights 'usually occurred in response to the demand of some well-defined contender or coalition of contenders' ${ }^{27}$ 'Organization gave working people the strength to demand their rights. The acquisition of those rights brought expanded use of them in formulating new demands or pursuing old ones. The sequence ... is a general rule for collective action. ${ }^{28}$

In the emerging latecomer polities, the character of collective action was different. The state apparatus was usually not 'internal' to the same extent, and therefore major crises did not result from demands made by ethnically distinct subject populations but rather arose from international conflicts and their impact on the fragile mother empires. Fluctuation between extreme repression and temporary liberalisation was much more likely than in the major Western states. Opportunities sometimes changed rapidly and quite independently of the strength of collective action. It may be argued, for example, that the Russo-Japanese War had a much greater impact on the introduction of universal suffrage in Finland in 1906 than did the demands of domestic contenders in preceding years. The collapse of the Russian and Austro-Hungarian empires in World War I and the effect of this on the constituent nationalities were the final results of this process.

It seems reasonable to hypothesise that different opportunity structures produced differences in organisation and mobilisation. In Finland the peculiar character of the early working-class movement, which played a decisive part in the abortive revolution of 1917-18, can be traced to the opportunities at the beginning of the century.

In sum, the state-making histories of the old and the new polities varied systematically, and Finland was undoubtedly one of the latter. Its state apparatus was dependent on the mother empire; it was economically dependent on the Western market; ethnic considerations played a prominent part in the state-

25 Moore 1966; Tilly, Tilly and Tilly 1975; Thompson 1963.

26 Abendroth 1965, esp. pp. 51-86; Tilly 1978, p. 113 .

27 Tilly 1978, pp. 170-1.

28 Tilly, Tilly and Tilly 1975, p. 28o. 
making process; and finally, opportunities sometimes changed independent of the strength of domestic collective action. But, quite importantly, Finland resembled the other new polities in political dependence much more than in the character of the class structure or the nature of economic dependence. Among the smaller European regions experiencing a serious revolutionary challenge at the end of World War I, Finland was practically the only one to have a decidedly non-feudal class structure. ${ }^{29}$ Finland's distinctiveness stems from the fact that, in the longer run, it was not just a minority region in a multinational empire; rather, it was a territory between two established members of the international state system. Before the nineteenth century, the Finnishlanguage areas that were to form the bulk of present-day Finland belonged to Sweden. Finland's class structure, which was similar to Sweden's and Norway's, had its origins in this earlier period. This fact has direct implications for the character of subsequent collective action, but it also implies that economic dependence on the Western market did not have the same consequences as in the East.

The specifically Finnish combination - a decisive similarity with Eastern successor states in political dependence on the one hand, and with Scandinavia in class structure and economic dependence on the other - makes the analysis of a political, economic, and cultural interface necessary. The Scandinavian countries cannot be omitted, even if the most important comparison is with Eastern Europe.

\section{What Is to Be Explained}

In the nineteenth century, Finland was characterised by nearly complete social tranquillity and a very conservative political system. But the first elections based on universal suffrage were held as early as 1907, and they gave the Social Democrats the largest share of seats in any European country, even though Finland was one of the most agrarian countries in Europe. Almost nine-tenths of the votes cast for the Social Democrats came from the countryside. Rural voters were in the majority in both absolute and relative terms, and the party was not only strongly supported but also well organised in the countryside. Dur-

29 Bohemia resembled Finland the most in this respect. Whereas peasant landownership was extensive in the Balkans, farms there were fragmented and scarcely viable compared to those of the Finnish landowning class. See Berend and Ránki 1974, pp. 49-52; and below, Chapter 3 . 
ing the following decade this party was gradually integrated into the prevailing political system. Nonetheless, in 1918, immediately after Finland became independent, it spearheaded an abortive revolution. Finally, a little over a decade later, a powerful fascist-type movement emerged and attempted to overthrow the Finnish parliamentary political system.

These are the main processes to be explained in this study: the entrance of the masses onto the political scene in 1907, the rise and failure of the revolution of 1918, and the fascist-type reaction of the early 1930s. These phenomena took place in a region that was or had just ceased to be a politically autonomous part of the Russian Empire and had close economic links with the West. To make sense of these processes, a number of questions must be answered. What were the roles of the external and internal forces in the formation of the Finnish state and in the creation of preconditions for collective action in it? How did the outside factors and their intertwining with domestic structures affect, first, early political mobilisation and, second, the outbreak of revolution in 1918? Finally, what was the impact of the failure of the revolution on state structures and conflicts in the 1920 and 1930s?

These questions may be viewed as problems involving relations between the state and class structures in Finland and the organisation at their intersection - an organisation reflected in the nature of national and class integration. All four processes should be viewed as dependent on external forces. In this perspective, the first phenomenon that needs to be examined is the consolidation of the Finnish state, and particularly its relation both to the system of established states in Europe and to the capitalist world economy. Second, the class structure and the impact of the world market on it are to be considered. Here the third and fourth processes, linked to the role of the various classes in the emerging Finnish state, become relevant. In what ways were political developments in the mother country mediated into the Finnish state and class structures, thus reshaping their mutual relations? What were the roles of domestic and non-domestic forces in Finnish nationalism and early twentieth-century politics? Moreover, how did the endogenous and exogenous factors influence the process of political mobilisation in 1917 and 1918, after the collapse of Imperial Russia? Finally, the consequences of the abortive revolution for the state and the classes in the newly independent republic will be assessed.

The class relations that were institutionalised in the Finnish state through specific forms of national and class integration during the nineteenth century will be delineated first. Then the picture will be fleshed out by an examination of the sudden disruptions in state control that came about because of interstate rivalries damaging to Russia. The question is, how did earlier Finnish struc- 
tures and forms of integration become effective in the crisis, and what then happened to them? Reduced to its barest essentials, then, the theme of this book is the interplay between institutionalised domestic class relations and fluctuations in the controlling capacity of the state resulting from oscillations in the mother empire.

After considering these questions it will be possible to judge the relevance of other Eastern European cases for Finland, as well as the relevance of the Finnish case for them, in terms of classes, state formation, and problems of organisation.

The book is divided into four parts, dealing first with fundamental state-making processes and class relations (Part I), national integration and class integration (Part II), and the rupture of integration in the abortive revolution (Part III). Then an attempt is made to place Finnish developments in a European perspective (Part IV).

In Part I the formation of the Finnish state and its linkages with the development of the class structure are delineated. The process of state-making and the shifting relations among the upper classes bear the marks of Finland's position in the interface between Sweden and Russia. When the Finnish regions were transferred from Sweden to Russia and made into a separate political unit, the relations between the dominant groups were redefined. Then, a halfcentury later, they were completed and modified by capitalist development. In the consolidation of the economy, Finland benefited greatly from its Scandinavian social structure and its status as an 'overdeveloped' minority region in a multinational empire. From this double point of departure, a Western type of social structure and an Eastern type of dependence, Finland was able to start a process of economically autonomous development in the latter part of the nineteenth century (Chapter 2).

In this process close ties developed between the agrarian and the industrial proletariat. Finland's main industrial sector, forestry, was strongly and very directly linked to the countryside because the peasants owned the bulk of the forests. Consequently, the capitalist transformation was felt immediately and profoundly in both town and country (Chapter 3).

Another aspect of the process of state-making and, notably, of the formation of a national economy was territorial integration. During the Swedish period the Finnish regions interacted mainly with an external core, Stockholm. In the nineteenth century, however, after tentative and partial reorientation toward 
St. Petersburg, a domestic core emerged. A geographical division of labour was established, which tied the various regions together in a more fundamental sense than ever before and accentuated a number of regional inequalities (Chapter 4).

Part II lays out the interrelationship between the state and the class structures in the process of organisation. The starting point is Finland's resemblance to Scandinavia, on the one hand, in its basic patterns of organisation and mobilisation, and to other minor nationalities in the large empires, on the other, in its opportunities for collective action.

The national movement was a struggle for self-assertion and liberation, but at the same time it served for the dominant classes as a 'civic religion' for the emerging state, thanks to the early foundation of the Finnish polity by the Russian imperial authorities. The latter aspect of the national movement was intensified by the strength of the Finnish-speaking peasantry; because the authority of the Swedish-speaking upper classes rested structurally on a fragile foundation, their national responsiveness was enhanced. It is mainly because of this combination - so it is argued - that national consolidation occurred in Finland, and nationalism advanced exceptionally calmly and steadily (Chapter 5 ).

Although the emerging party system closely resembled the Scandinavian one, the political opportunity granted by the first Russian revolution in 19056 made the main challenger, the worker movement, focus overwhelmingly on purely political and, more particularly, parliamentary action, at the expense of strikes and other forms of collective action based directly on productive relations. Strong agrarian support for the Social Democratic party worked in the same direction. The movement rapidly attained membership in the polity and became a powerful instrument in both class and national integration (Chapter 6).

The emergence of regionally varying party support is another indicator of national integration. The persistence of regional conflicts is manifest in the combinations of party support, which differed from region to region. But because all important parties played a national role, it is reasonable to view the regional combinations as the way in which local conflicts were fused on the emerging national level (Chapter 7 ).

In Part III the disruption of metropolitan control and its domestic consequences during and after World War I are brought into play. Arguably, it was the strong position of the rather reformist worker movement in the polity, combined with the opportunity for collective action provided by the breakdown of the Russian Empire, that led Finland into a revolutionary situation. The Finnish case illustrates the primacy of changes in conditions for contests concerning 
state power and suggests that whether or not the challengers consider themselves revolutionaries at the outset is of secondary importance (Chapters 8 and 9).

The failed revolution marked the creation of an independent country out of a grand duchy, and especially out of the national and class integration consolidated in the previous phase of state-making. The earlier national culture provided the instruments for defining and analysing the seemingly surprising and incomprehensible developments of 1917-18. From this perspective, the Finnish fascist movement of the early 193os appears to be basically a general bourgeois reaction, an attempt to reassert the White victory of 1918 (Chapter 10).

Finally, Part IV (Chapters 11 and 12) focuses both on features that Finland had in common with other Eastern European minority regions and latecomer polities and on features that differentiated Finland from them. The country's interface position seems crucial: Finland emerges as a kind of mixed case in which, curiously enough, a class structure and political system of a Western type and a sudden collapse of an Eastern type coincided to ignite a revolution. The former had granted the Social Democrats a central place in the representative political institutions of the country; the latter granted them an extremely advantageous opportunity to use this power. The revolutionary situation emerged when the labour movement attempted to maintain power and the particular advantages it had gained in the face of a resolute bourgeois effort to recapture a monopoly on power. This was very unlike the Baltic Provinces, where the revolutionaries really seized power, or Hungary, where they simply accepted it - in both cases after war had destroyed the state apparatus. 